\title{
Article \\ Bioassay-Guided Identification of Bioactive Compounds from Senna alata L. against Methicillin-Resistant Staphylococcus aureus
}

\author{
Suwaiba Ladan Muhammad ${ }^{1, *}$, Yusuf Wada ${ }^{2,3}$, Mustapha Mohammed ${ }^{4,5, *}$, Sani Ibrahim ${ }^{6}$, Kabir Yusuf Musa ${ }^{7}$, \\ Olayeni Stephen Olonitola ${ }^{8}$, Mubarak Hussaini Ahmad 9 ${ }^{\mathbb{D}}$, Sagir Mustapha 9,10 ${ }^{\mathbb{D}}$, Zaidah Abdul Rahman ${ }^{2,11}$ \\ and Abubakar Sha'aban 4,5 (D)
}

Citation: Muhammad, S.L.; Wada, Y.; Mohammed, M.; Ibrahim, S.; Musa, K.Y.; Olonitola, O.S.; Ahmad, M.H.; Mustapha, S.; Abdul Rahman, Z.; Sha'aban, A. Bioassay-Guided Identification of Bioactive Compounds from Senna alata L. against Methicillin-Resistant Staphylococcus aureus. Appl. Microbiol. 2021, 1, 520-536. https://doi.org/ 10.3390/applmicrobiol1030034

Academic Editor: Marina Spinu

Received: 9 September 2021 Accepted: 2 November 2021 Published: 15 November 2021

Publisher's Note: MDPI stays neutral with regard to jurisdictional claims in published maps and institutional affiliations.

Copyright: (c) 2021 by the authors. Licensee MDPI, Basel, Switzerland. This article is an open access article distributed under the terms and conditions of the Creative Commons Attribution (CC BY) license (https:// creativecommons.org/licenses/by/ $4.0 /)$.
1 Department of Chemical Science, Federal Universiti of Kashere, Gombe PMB 0182, Gombe State, Nigeria

2 Department of Medical Microbiology and Parasitology, School of Medical Sciences, Universiti Sains Malaysia, Kubang Kerian 16150, Kelantan, Malaysia; wadayusuf34@gmail.com (Y.W.); drzaidah@usm.my (Z.A.R.)

3 Department of Zoology, Faculty of Life Sciences, Ahmadu Bello University, Zaria 810107, Kaduna, Nigeria

4 School of Pharmaceutical Sciences, Universiti Sains Malaysia, Minden 11800, Pulau Pinang, Malaysia; abuushaaban2@gmail.com

5 Department of Clinical Pharmacy and Pharmacy Practice, Faculty of Pharmaceutical Sciences, Ahmadu Bello University, Zaria 810107, Kaduna, Nigeria

6 Department of Biochemistry, Faculty of Life Sciences, Ahmadu Bello University, Zaria 810107, Kaduna, Nigeria; sanibro2000@yahoo.com

7 Department of Pharmacognosy and Drug Development, Ahmadu Bello University, Zaria 810107, Kaduna, Nigeria; drashrafamjad921@gmail.com

8 Department of Microbiology, Faculty of Life Sciences, Ahmadu Bello University, Zaria 810107, Kaduna, Nigeria; olonisteve@gmail.com

9 Department of Pharmacology and Therapeutics, Faculty of Pharmaceutical Sciences, Ahmadu Bello University, Zaria 810107, Kaduna, Nigeria; mubarakhussainiahmad@gmail.com (M.H.A.); maimunat001@gmail.com (S.M.)

10 Department of Pharmacology, School of Medical Sciences, Universiti Sains Malaysia, Kubang Kerian 16150, Kelantan, Malaysia

11 Hospital Universiti Sains Malaysia, Universiti Sains Malaysia, Kubang Kerian 16150, Kelantan, Malaysia

* Correspondence: suwaibana@gmail.com (S.M.L.); mohammedmmrx@gmail.com (M.M.)

Abstract: Senna alata (Linn) Roxb. plant is widely used to manage various infections in folkloric medicine. Methicillin-resistant Staphylococcus aureus (MRSA) infection continues to be a major global public health problem. This study aims to investigate the bioactive components of S. alata leaves active against MRSA. The leaves of $S$. alata were sequentially extracted and fractionated using standard methods and screened for activities against MRSA. The diethyl ether active thin layer chromatography (TLC) spot was subjected to infrared (IR) and gas chromatography-mass spectroscopic (GC-MS) studies. The aqueous extract and diethyl ether fraction of $S$. alata leaves elicited the highest activity against the MRSA. The GC-MS analysis of the fraction produced 15 eluates; only the sub-fraction 13 was effective. The TLC analysis of the sub-fraction 13 revealed three spots; only the second spot produced activity. The GC-MS result of the spot showed six peaks. The spectral results for peak 3 match the data from the IR study, suggestive of 9-octadecenoic acid methyl ester. Senna alata leaves possess bioactive compounds closely related to 9-octadecenoic acid methyl ester with potent antibacterial activity against MRSA.

Keywords: bioassay; chromatography; folkloric medicine; methicillin-resistant Staphylococcus aureus; Senna alata; spectroscopy

\section{Introduction}

Infectious diseases are among the top causes of global mortality, morbidity, and disability [1,2]. The pathogens such as Staphylococcus aureus form a serious burden on 
health due to related infections, including pneumonia, endocarditis, and sepsis [3,4]. The methicillin-resistant Staphylococcus aureus (MRSA) is one of the most critical multidrugresistant (MDR) pathogens mostly encountered in hospitals $[3,5,6]$. The global incidence of MRSA infection has increased the burden on the health care system and overall mortality over the years [5]. Additionally, the MRSA infection still extends to the community population [3]. Due to the frequent emergence of antimicrobial resistance, limited options are available for treating MRSA-related infections [7]. The ineffectiveness of the available antibacterial agents necessitates the search for new compounds for use against resistant bacteria [8].

Plants have contributed to the general health and well-being of the populace for a long time [2]. About $75 \%$ of the people globally depend on traditional medicine for their basic health requirements [9]. Many therapeutic compounds employed in orthodox medicine originate from plants [10]. Plants synthesize various secondary metabolites with different chemical diversity and biological actions [11]. Plants and their secondary metabolites have been reported to serve as sources of antimicrobial agents [6,12-14]. For years, attention has been shifted to investigate phytochemical compounds with potential antibacterial activity, particularly against MDR bacteria [13]. Given the roles of medicinal plants in curtailing infectious diseases, there is a need to continue the search for novel therapeutic agents to pave the way for the discovery of new therapeutic agents $[15,16]$.

The plant Senna alata (Linn) Roxb. synonymous with Cassia alata (Leguminosae), is commonly distributed in Asia, Brazil, Australia, and many African nations, including Egypt, Somalia, and Nigeria [16]. The plant is a tropically erect annual herb that grows up to $2-5 \mathrm{~m}$ high. It possesses big, leathery, and slippery compound bilateral leaves that usually fold at night [17]. It has a pod fruit with small and square-shaped seeds [18]. In English, this medicinally important plant is called candle bush, craw-craw, Acapulco or ringworm bush plant [16]. The local names of the plant are Asunwon oyinbo in Yoruba, Nelkhi in Igbo, and Hantsi in the Hausa languages of Nigeria [17]. The plant is used as herbal preparation to manage hepatitis, gastroenteritis, constipation, dermatitis, eczema, jaundice, diarrhea [18], and bacterial infections [19]. The plant's leaves, stems, and roots have been ingested as a decoction to treat wounds, the respiratory tract, and skin infections in Northern Nigeria [18]. Additionally, in Cameroon, the leaves, stems, and bark of S. alata were documented to be used to treat gastroenteritis and skin infections [16]. Its leaves, bark, and stem are effective against intestinal parasitosis and syphilis as a decoction in China, the Philippines, and India [20]. Keeping in view the ethnopharmacological indication and promising therapeutic properties of $S$. alata for treating infectious ailments, this study was conducted to screen the leaves extracts of $S$. alata for activity against MRSA, and identify the bioactive compounds likely responsible for the activity.

\section{Materials and Methods}

\subsection{Plant Collection and Identification}

The whole plant Senna alata was sourced from Jaji village, along Kaduna-Zaria Road, Kaduna State of Nigeria. The authentication of the plant material was conducted at the Herbarium section of the Biological Science Department, Ahmadu Bello University (ABU), Zaria, Nigeria. The herbarium specimen voucher number obtained was 2421.

\subsection{Extraction and Fractionation}

The extraction and fractionation were conducted based on the procedures used by Kupchan et al. (1973) [21]. The fresh leaves of the S. alata were kept to dry under shade until a uniform weight was attained. The dried leaves were powdered using mortar and pestle into fine particles, packaged in a tightly closed container, and kept in a cool and dry environment. The Soxhlet apparatus exhaustively extracted one kilogram $(1 \mathrm{~kg})$ of the dried powdered S. alata leaves with 2.5 Liters (L) of petroleum ether ( $60-80$ grades). The marc of the petroleum ether extraction was then extracted with $2.5 \mathrm{~L}$ absolute methanol with the aid of the Soxhlet apparatus. The marc of the methanolic extraction was dried 
and percolated with 1000 milliliters (mL) deionized water for 24 hours $(\mathrm{h})$ for the aqueous extraction. The extracts (petroleum ether, methanolic, and aqueous) were concentrated separately on a water bath set at $45^{\circ} \mathrm{C}$. The values for the percentage yield of the extracts were calculated using Equation (1).

$$
\text { Percentage yield }(\%)=\frac{\text { Weight of the crude extract }(\mathrm{g})}{\text { Weight of the powdered plant material }(\mathrm{g})} \times 100
$$

One hundred grams (100 g) of the crude aqueous extract was suspended in water $(500 \mathrm{~mL})$ and successively partitioned with ethyl-acetate $(5 \times 500 \mathrm{~mL})$ and diethyl ether $(5 \times 500 \mathrm{~mL})$ to form the corresponding fractions. The ethyl-acetate and diethyl ether were evaporated to dryness, while the residual aqueous was removed by placing the fraction on a water bath set at $50{ }^{\circ} \mathrm{C}$. The fractions were stored in a container separately before use. Each fraction was made into solutions with distilled water for each experiment. The percentage yield for each fraction was determined according to the formula above.

\subsection{Phytochemical Studies}

Qualitative and quantitative phytochemical investigations were performed on the crude aqueous leaves extract of $S$. alata to test the occurrence of phytochemical constituents in the extract according to the procedure outlined by Sofowora (1993) [22].

\subsubsection{Qualitative Phytochemical Studies}

Test for Alkaloids

One gram ( $1 \mathrm{~g})$ of the crude aqueous leaves extract of $S$. alata was boiled in a test tube containing $10 \mathrm{~mL}$ of acid alcohol on a water bath, allowed to cool, and filtered. To the filtrate, three drops of Dragendorf's reagent were added. The occurrence of an orange-red precipitate indicated the presence of alkaloids.

\section{Test for Tannins}

Lead acetate test-Two milliliters $(2 \mathrm{~mL})$ of the crude aqueous leaves extract of $S$. alata was diluted with an equal volume of water $(2 \mathrm{~mL})$. Five drops of lead acetate solution were added. The black-green colored precipitate formed revealed the presence of tannins.

\section{Test for Phenolic Derivatives}

Two milliliters $(2 \mathrm{~mL})$ of the crude aqueous leaves extract of $S$. alata was diluted with 2-3 drops of 5\% ferric chloride solution. The mixture formed blackish-green coloration indicating the presence of phenolic compound(s).

\section{Test for Anthracene Derivatives}

Four milliliters $(4 \mathrm{~mL})$ of the crude aqueous leaves extract of $S$. alata was concentrated to $2 \mathrm{~mL}$ and was hydrolyzed with $10 \%$ hydrochloric acid $(\mathrm{HCl})$ solution. Two milliliters $(2 \mathrm{~mL})$ of $25 \%$ ammonia solution was added to the mixture with gentle shaking. A cherishred color observed with the alkaline solution indicated the presence of emodols aglycones of anthracenoside in an oxidized form.

\section{Test for Anthracenoside}

Bontrager's reaction- $10 \%$ of $\mathrm{HCl}$ was added to $25 \mathrm{~mL}$ of the crude aqueous leaves extract of $S$. alata. The mixture was refluxed and heated for $30 \mathrm{~min}$. During the hydrolysis, the solution became opalescent. After cooling, the solution was extracted three times in a separating funnel with ethyl ether $(10-12 \mathrm{~mL})$. The extracts were pooled together and dehydrated with anhydrous sodium sulphate. This resulted in ether and aqueous fractions. The ether and aqueous extracts were separated. The acidic aqueous solution was red, which does not change to violet at neutral $\mathrm{pH}$, or green or blue in an alkaline medium, indicating the presence of anthracenoside. The ether fraction was used to test the presence of emodols and coumarins. 
Test for Emodols

Four milliliters $(4 \mathrm{~mL})$ of the ether extract above was concentrated to $2 \mathrm{~mL}$. Two milliliters $(2 \mathrm{~mL})$ of $25 \%$ ammonia solution was added and shaken. A cherish-red color observed indicated the presence of emodols aglycones of anthracenoside.

\section{Test for Coumarin Derivatives}

Another four milliliters $(4 \mathrm{~mL})$ portion of the ether extract above was evaporated to dryness. The residue was dissolved by heating in $2 \mathrm{~mL}$ of water. The aqueous solution was divided into two equal volumes in two test tubes (A and B). To test tube A, $0.5 \mathrm{~mL}$ of $10 \%$ ammonia solution was added, while the content of test tube B served as a reference. The appearance of blue fluorescence under ultraviolet (UV) light indicated the presence of coumarin.

Test for Steroid Glycosides

Lieberman-Burchardreaction-Ten milliliters $(10 \mathrm{~mL})$ of the ether extract above was evaporated to dryness. The residue was dissolved in acetic anhydride $(0.5 \mathrm{~mL})$ and chloroform $(0.5 \mathrm{~mL})$. The solutions were transferred to a dry test tube. Then, $2 \mathrm{~mL}$ of concentrated sulphuric acid was added to the bottom of the tube. The appearance of bluish-green and violet coloration revealed the presence of sterol glycosides and triterpenes, respectively.

\section{Test for Flavonoids}

Shinoda's test-The $100 \mathrm{mg}$ of the powdered aqueous leaves extract of S. alata was dissolved in $2 \mathrm{~mL}$ of $50 \%$ methanol and heated in a water bath. Then, some pieces of metallic magnesium and six drops of concentrated $\mathrm{HCl}$ were added. The solution turned reddish, indicating the presence of flavonoids.

Sodium hydroxide test-To an equal volume of the crude aqueous leaves extract of S. alata, $5 \mathrm{~mL}$ of $10 \%$ sodium hydroxide $(\mathrm{NaOH})$ solution was added. A yellow coloration indicated the presence of flavonoids.

\section{Test for Tannins}

Ferric chloride test-To one milliliter $(1 \mathrm{~mL})$ of the crude leaves aqueous extract of S. alata, 3 drops of ferric chloride solution were added. The formation of greenish-black precipitate indicated the presence of condensed tannins.

Lead sub-acetate test-The crude aqueous leaves extract of S. alata $(0.5 \mathrm{~g})$ was dissolved in $2 \mathrm{~mL}$ of water. Then, lead sub-acetate solution (3 drops) were added. The formation of a black-green colored precipitate indicated the presence of tannins.

\section{Test for Saponins}

Frothing test-Two milliliters $(2 \mathrm{~mL})$ of the crude aqueous extract were diluted in a ratio of $1: 1$ in a test tube of $(1.6 \mathrm{~cm}$ diameter $)$ and shaken. The occurrence of foam of $1 \mathrm{~cm}$ height, which persisted for $15 \mathrm{~min}$, was observed, which revealed the presence of saponins.

Hemolytic Test-To two test tubes $\left(t_{1}\right.$ and $\left.t_{2}\right)$ had $1.8 \%(w / v)$ sodium chloride $(\mathrm{NaCl})$ solutions added to each. Two milliliters $(2 \mathrm{~mL})$ of deionized water was added to test tube one $\left(t_{1}\right)$, while $2 \mathrm{~mL}$ of the extract was added to test tube two $\left(t_{2}\right)$. The concentrations in each of the tubes were made isotonic with blood serum. The blood was obtained by pricking the thumb at the base of the nail. The blood was drawn into a small pipette. Five drops of the blood were added to each of the two test tubes. The tubes were stoppered and inverted gently to mix the contents and allowed to stand for some time. Hemolysis in the test tube containing the extract $\left(t_{2}\right)$ and not in control $\left(t_{1}\right)$ was observed, indicating the presence of saponins.

\section{Test for Resins}

Two grams ( $2 \mathrm{~g}$ ) of the crude aqueous leaves extract of $S$. alata was dissolved in $10 \mathrm{~mL}$ of acetic anhydride in a test tube. One drop of concentrated sulphuric acid was added. 
A purple color, which rapidly changed to violet, was observed, showing the presence of resins.

\subsubsection{Quantitative Phytochemicals Study}

Alkaloid Determination

Ten grams $(10 \mathrm{~g})$ of the crude aqueous leaves extract of $S$. alata was weighed into a $250 \mathrm{~mL}$ beaker, and $100 \mathrm{~mL}$ of $10 \%$ acetic acid in ethanol was added, covered, and allowed to stand at room temperature for $4 \mathrm{~h}$, then filtered with Whatman No.1 filter paper. The filtrate was concentrated on a water bath to one-quarter of the original volume. Then, concentrated ammonium hydroxide was added drop-wise to the extract until precipitation was completed by obtaining full turbidity. This whole solution was allowed to settle and filtered with filter paper. The precipitate was washed with dilute ammonium hydroxide solution. The residue is the alkaloid, which was dried in an oven at $100{ }^{\circ} \mathrm{C}$ for an hour, cooled in a desiccator, and weighed. The weight of the alkaloid was determined by difference and was expressed as a percentage of the sample analyzed (Harborne, 1973) [23].

\section{Alkaloid Determination}

Ten grams $(10 \mathrm{~g})$ of crude aqueous leaves extract of $S$. alata boiled in $100 \mathrm{~mL}$ of $2 \%$ $\mathrm{HCl}$ solution for $35 \mathrm{~min}$ and filtered with Whatman filter paper No. $42(125 \mathrm{~mm})$. A few drops of ethyl-acetate were added to the filtrate. A precipitated flavonoid was recovered by filtration through a pre-weighted filter paper which was dried in an oven at $100{ }^{\circ} \mathrm{C}$ for $30 \mathrm{~min}$, cooled in a desiccator and re-weighed (Bohm and Kocipai-Abyazan, 1994) [24].

\section{Tannins Determination}

The Follins-Dennis Spectrophotometric method: $1 \mathrm{~g}$ of the crude aqueous leaves extract of $S$. alata was dispersed in $10 \mathrm{~mL}$ distilled water, agitated, and allowed to stand for $30 \mathrm{~min}$ at room temperature with shaking every $5 \mathrm{~min}$. The mixture was centrifuged, and the extract was obtained. Then, $2.5 \mathrm{~mL}$ of the supernatant (extract) was dispersed into a $50 \mathrm{~mL}$ volumetric flask. Similarly, $2.5 \mathrm{~mL}$ of standard tannic acid solution was dispersed into another separate $50 \mathrm{~mL}$ flask. Then, $1 \mathrm{~mL}$ of Folin Denis reagent was measured into each flask, followed by $2.5 \mathrm{~mL}$ of saturated $\mathrm{Na}_{2} \mathrm{CO}_{2}$ solution. The mixture was diluted in the flask $50 \mathrm{~mL}$ and incubated for $90 \mathrm{~min}$ at room temperature. The absorbance was measured at $760 \mathrm{~nm}$ in a Genway model 6000 electronic spectrophotometer (GenWay Biotech Inc., San Diego, CA, USA). The experiment was repeated three times to achieve an average (Pearson, 1976) [25].

\section{Cyanogenic Glycosides Determination}

The protocol described by Onwuka (2005) [26] was used: $5 \mathrm{~g}$ of the crude aqueous leaves extract of $S$. alata was made into a paste, dissolved into $50 \mathrm{~mL}$ distilled water, and filtered. To $1 \mathrm{~mL}$ of the filtrate, $4 \mathrm{~mL}$ of alkaline picrate was added, absorbance was recorded at $550 \mathrm{~nm}$, and cyanide content was extrapolated from a cyanide standard curve.

\section{Saponins Determination}

The gravimetric method of AOAC (1984) [27] using a soxhlet extractor and two different organic solvents were used. Next, $10 \mathrm{~g}$ of the dried ground sample was weighed into a thimble and transferred into a soxhlet extractor chamber fitted with a condenser and a flat bottom flask. Then, $500 \mathrm{~mL}$ of acetone was poured into the flask. The sample's lipid and interfering pigments were exhaustively extracted, and the solvent distilled off by heating the flask on a hot plate for $3 \mathrm{~h}$. Then, the second extraction was conducted, a pre-weighed round bottom flask was fitted into the soxhlet apparatus (bearing the sample containing thimble), and methanol was poured into the flask. The methanol was enough to cause reflux. The saponins were then exhaustively extracted for $3 \mathrm{~h}$ by heating the flask on a hot plate, after which the solvent was distilled off. The flask was re-weighed. The 
difference between the final and initial weights of the flask represented the quantity of saponins extracted.

\subsection{Test Organism}

The procedure previously used by Devillers et al. (1989) [28] was adopted. The methicillin-resistant Staphylococcus aureus (MRSA) was sub-cultured on sterile Nutrient Agar (NA) plates and incubated at $37^{\circ} \mathrm{C}$ for $48 \mathrm{~h}$ before each antibacterial testing.

\subsection{Preparation of the Test Organism (MRSA)}

The test organism used for the study was a standard strain of MRSA (ATCC33591) obtained from the Department of Veterinary Public Health, Ahmadu Bello University, Zaria, Kaduna, Nigeria.

2.6. Antibacterial Screening of Senna alata Leaves Extracts and Fractions against MRSA by Agar Well Diffusion Method

The various extracts (petroleum ether, methanol, and aqueous) and the aqueous fractions (ethyl acetate, diethyl ether, and aqueous) of $S$. alata leaves were investigated for antibacterial effect against MRSA by agar well diffusion procedure as reported by Devillers et al. (1989) [28]. In this method, a $24 \mathrm{~h}$ culture of MRSA was suspended in a sterile bottle that contained nutrient broth. Gradually, normal saline was added to obtain turbidity identical to Marcfland standard 0.5 , which corresponds to about $10^{8}$ cells $/ \mathrm{mL}$. This was then diluted to produce $10^{6}$ cells $/ \mathrm{mL}$ used in the experiment. Then, $1 \mathrm{~mL}$ of the test organism $\left(10^{6}\right.$ cells $\left./ \mathrm{mL}\right)$ was inoculated into Petri plates $(90 \mathrm{~mm}$ diameter) for the antibacterial susceptibility test. Then, wells ( $6 \mathrm{~mm}$ diameter and $4 \mathrm{~mm}$ deep) were punched in the agar using a sterile cork borer. The wells were bored such that they were not closer than $15 \mathrm{~mm}$ to the edge of the plate, and far enough apart to overcome overlapping the inhibition zones. Some of the wells were filled with $25 \mathrm{mg} / \mathrm{mL}$ of either one extract or fractions, while some were filled up with one of the solvents as control. An adequate time was given to allow the material to diffuse considerably into each of the media. The plates were then turned upside down and kept in an incubator at $36^{\circ} \mathrm{C}$ for $48 \mathrm{~h}$. Subsequently, the various inhibition zones were observed as an index of antibacterial activity.

\subsubsection{Determination of the Zone of Inhibition for Agar Well Diffusion Method}

Following the incubation, the plates were checked for antibacterial activities. The compounds of the discs diffused through the medium and formed a concentration gradient. Hence, the compounds of the wells formed in clear round zones of inhibition, which were measured with naked eyes using a transparent scale.

\subsection{Thin-Layer Chromatographic Analysis of Diethyl Ether Fraction Obtained from Senna alata crude aqueous Leaves Extract}

The most active fraction (diethyl ether) of aqueous extract of $S$. alata leaves was investigated for the active compound using thin-layer chromatography (TLC). The TLC analysis was performed on pre-coated silica gel TLC plates (60 F254) and subsequently developed by two solvent systems of different polarities; $n$-butanol: acetic acid: water (6:1:2) and chloroform: acetic acid (9:1). The crude diethyl ether fraction was dissolved in methanol, spotted on the pre-coated G60 F254 TLC plates, and developed in each solvent system. The various spots were detected using the following detecting agents; iodine vapor, ammonia vapor, ultraviolet (UV) light at $366 \mathrm{~nm}$ and UV in ammonia. The number of spots, colors, and retardation factors (Rf) values for each spot were calculated. The presence of compounds was suggested by comparing the observations with the standards from the literature [29]. The $\mathrm{Rf}$ was calculated by Equation (2). The agar overlay protocol investigated the various spots of the crude diethyl ether fraction for activity against MRSA.

$$
\text { Retention factor }(\mathrm{Rf})=\frac{\text { Distance spot moved }}{\text { Distance solvent moved }}
$$


2.8. Antibacterial Screening of Various TLC Spots Obtained from Diethyl Ether Fraction of Senna alata crude aqueous Leaves Extract against MRSA by Agar Overlay Method

Three milliliters $(3 \mathrm{~mL})$ of nutrient broth in a sterile capped tube were inoculated with MRSA. The inoculated bottle was incubated in an incubator at $37{ }^{\circ} \mathrm{C}$ for $48 \mathrm{~h}$. The developed TLC plates were aseptically placed in sterile Petri dishes. About $15 \mathrm{~mL}$ of melted top NA was measured using a pipette into three (3) different sterile capped bottles and allowed to cool to about $45^{\circ} \mathrm{C}$. To each bottle containing the melted NA, about $0.8 \mathrm{~mL}$ of the nutrient broth containing MRSA was pipetted and vortexed to mix the test organism. The content of each bottle; melted top agar containing-MRSA was then poured onto each of the Petri dishes containing the developed TLC plates and control plates containing the unspotted TLC plates developed in the solvent system; chloroform: acetic acid (9:1). The plates were gently tilted back and forth to have an even distribution of the test organism, then allowed to gel fully and incubated at $37{ }^{\circ} \mathrm{C}$ for $48 \mathrm{~h}$. Subsequently, the various inhibition zones were measured as an index of antibacterial activity.

\subsubsection{Determination of the Zone of Inhibition for Agar Overlay Method}

The zones of inhibition were determined as described in Agar Well Diffusion method (Section 2.6.1.) above.

\subsection{Column Chromatographic Analysis of the Diethyl Ether Fraction Obtained from the Senna alata crude aqueous Leaf Extract}

The most active fraction (diethyl ether) was chromatographed over a silica gel column (mesh size: 70-230) and successively eluted with solvents to increase polarity using nhexane and ethyl-acetate. The eluates were then applied onto a pre-coated TLC card of silica gel 60G254 (thickness $0.1 \mathrm{~mm}$ ) plates and eluted with methanol: chloroform (4:1) [30]. The eluates with the same Rf values were pooled together. The column eluted with n-hexane: ethyl acetate (40:60) afforded the most active eluate.

\subsection{Gas Chromatography-Mass Spectrometry of the Active Spot (Spot 2)}

The TLC active spot (spot 2) was analyzed with a gas chromatography-mass spectrometry, GC-MS QP2010 PLUS analyzer (Shimadzu, Kyoto, Japan). The data were obtained on an elite-1 (100\% dimethyl polysiloxane) column $(30 \times 0.25 \mathrm{~mm} \times 1 \mu \mathrm{mdf})$. The carrier gas used was helium $(99.99 \%)$ with a flow rate of $1 \mathrm{ml} / \mathrm{min}$ in the split mode (10:1). An aliquot of $2 \mu \mathrm{L}$ of ethanol solution of the sample was injected into the column with the injector temperature at $250{ }^{\circ} \mathrm{C}$. The gas chromatography (GC) oven temperature was started at $110{ }^{\circ} \mathrm{C}$ and held for $2 \mathrm{~min}$. The temperature was elevated to $200{ }^{\circ} \mathrm{C}$ at the rate of $10{ }^{\circ} \mathrm{C} / \mathrm{min}$ without holding. Holding was allowed at $280{ }^{\circ} \mathrm{C}$ for $9 \mathrm{~min}$ with a program rate of $5^{\circ} \mathrm{C} / \mathrm{min}$. The temperature of the injector and detector were set at $250^{\circ} \mathrm{C}$ and $280^{\circ} \mathrm{C}$, respectively. Ion source temperature was maintained at $200{ }^{\circ} \mathrm{C}$. The mass spectrum of compounds in the samples was obtained by electron ionization at $70 \mathrm{eV}$, and the detector was operated in scan mode from 45-450 atomic mass units (amu). A scan interval of $0.5 \mathrm{~s}$ and fragments from 45 to $450 \mathrm{Da}$ was maintained. The total running time was $36 \mathrm{~min}$.

\subsection{Infra-Red Spectroscopy of the Active Spot (Spot 2)}

The infra-red (IR) spectroscopic analysis of the active spot was carried out on the $\mathrm{KBr}$ disc using Agilent Technologies Cary 630 Fourier Transform Infrared Spectrophotometer (FTIR-630) (Agilent Technologies, Santa Clara, CA, USA).

\subsection{Data Analysis}

All experiments were evaluated in duplicate. The mean values and standard error (SE) were calculated for each sample. The SE was calculated by taking the dispersion of the datasets relative to the means divided by the square roots of the sample size. Data analysis was performed using the Microsoft Office 365 software (Microsoft, CA, USA, 2020). 


\section{Results}

\subsection{Percentage Yield of the Senna alata Leaves Extracts}

The sequential extraction of one kilogram $(1 \mathrm{~kg})$ of the powdered S. alata leaves with petroleum ether, methanol, and water yielded $150.21 \mathrm{~g}$, $104.03 \mathrm{~g}$, and $204.57 \mathrm{~g}$, representing an extractive value of $15.02 \%, 10.40 \%$, and $20.46 \%$, respectively (Table 1 ).

Table 1. Percentage yield of the petroleum ether, methanol, and aqueous extracts of $S$. alata leaves.

\begin{tabular}{ccc}
\hline Extracts & Amount (g) & Yield (\%) \\
\hline Petroleum Ether & $150.21 \pm 1.68$ & $15.02 \pm 0.02$ \\
Methanol & $104.03 \pm 1.15$ & $10.40 \pm 0.04$ \\
Aqueous & $204.57 \pm 0.59$ & $20.46 \pm 0.05$ \\
\hline
\end{tabular}

\subsection{Percentage Yield Fractions per $100 \mathrm{~g}$ of S. alata crude aqueous Leaves Extract}

The partitioning of $100 \mathrm{~g}$ of the $S$. alata crude aqueous extract with ethyl-acetate, diethyl ether and the aqueous fraction yielded $1.68 \mathrm{~g}, 1.83 \mathrm{~g}$, and $2.45 \mathrm{~g}$ corresponding to $16.80 \%, 18.30 \%$, and $24.50 \%$ of the starting material, respectively (Table 2 ).

Table 2. Percentage yield of ethyl acetate, diethyl ether and aqueous fractions per $100 \mathrm{~g}$ of S. alata crude aqueous leaves extract.

\begin{tabular}{ccc}
\hline Fractions & Amount (g) & Yield (\%) \\
\hline Ethyl Acetate & $1.68 \pm 0.02$ & $16.08 \pm 0.01$ \\
Diethyl Ether & $1.83 \pm 0.01$ & $18.03 \pm 0.02$ \\
Aqueous & $2.45 \pm 0.31$ & $24.5 \pm 0.07$ \\
\hline
\end{tabular}

\subsection{Qualitative Phytochemicals Analysis of the Aqueous Leaves Extract of S. alata}

The qualitative phytochemical analysis of the crude aqueous leaves extract of $S$. alata indicated alkaloids, phenolic compounds, tannins, carbohydrates, reducing sugar, polyuronides, coumarins, saponins, steroids, triterpenoids, flavonoids, resins, cyanophores, cardiac glycosides, and anthraquinones. However, carotenoids were absent (Table 3).

Table 3. Photochemical constituents (qualitative) from the crude aqueous leaves extracts of $S$. alata.

\begin{tabular}{ccc}
\hline Constituents & Tests & Inference \\
\hline Alkaloid & Dragendorf's/Mayer's/Wagner's & + \\
Phenolic Compounds & Ferric Chloride's & + \\
Tannins & Lead Sub-acetate/Ferric Chloride & + \\
Carbohydrates & Molisch's & + \\
Reducing Sugars & Fehling's & + \\
Polyuronides & Methylene blue & + \\
Coumarins & Ammonia/UV light & + \\
Saponins & Frothing/Hemolysis & + \\
Steroids & Liebermann-Burchard's & + \\
Triterpenoids & Liebermann-Burchard's & + \\
Flavonoids & Lead acetate/Sodium hydroxide & + \\
Resins & Acetic anhydride/H SO $_{4}$ & + \\
Cyanophore & Guignard's & + \\
Glycosides & Fehling's/Ferric & + \\
Cardiac glycosides & Kelte killini/kadde's/Salkwoski's & - \\
Fixed oils and Fats & CuSO and NaOH solution & + \\
Carotenoids & Carl Price's reaction & + \\
Anthraquinones & $10 \%$ NH & +
\end{tabular}

Keys: (+) means present, $(-)$ means absent. 


\subsection{Quantitative Phytochemical Analysis of the Crude Aqueous Leaves Extract of S. alata}

The quantitative phytochemical investigation of the aqueous leaves extract of $S$. alata, showed that $10 \mathrm{~g}$ of the plant material contained $1.27 \mathrm{~g} \pm 0.02(12.7 \% \pm 0.01)$ of flavonoids, $0.30 \mathrm{~g} \pm 0.02(1.48 \% \pm 0.02)$ saponins, $0.64 \mathrm{~g} \pm 0.01(12.8 \% \pm 0.01)$ of alkaloids, $0.004 \mathrm{~g} \pm 0.01$ $(0.9 \% \pm 0.02)$ of cyanogenic glycosides, and $0.28 \mathrm{~g} \pm 0.01(9.6 \% \pm 0.01)$ of tannins (Table 4$)$.

Table 4. Quantitative determination of phytochemicals in $10 \mathrm{~g}$ of crude aqueous leaves extract of S. alata.

\begin{tabular}{ccc}
\hline Phytochemicals & Amount (g) & Yield (\%) \\
\hline Flavonoid & $1.27 \pm 0.02$ & $12.7 \pm 0.01$ \\
Saponins & $0.30 \pm 0.02$ & $1.48 \pm 0.02$ \\
Alkaloids & $0.64 \pm 0.01$ & $12.8 \pm 0.01$ \\
Cynogenic glycosides & $0.004 \pm 0.01$ & $0.9 \pm 0.02$ \\
Tannins & $0.28 \pm 0.01$ & $9.6 \pm 0.01$ \\
\hline
\end{tabular}

\subsection{Antibacterial Activities of Leaves Extract of S. alata}

The methanol and aqueous leaves extract of $S$. alata elicited remarkable inhibition against MRSA. However, the petroleum ether extract was not active against the bacterial isolate. The MRSA was resistant to the standard antibacterial agent used (oxacillin). The aqueous and methanol extracts exhibited the highest $(14.5 \mathrm{~mm} \pm 0.01)$ and lowest (11 $\mathrm{mm} \pm 0.11)$ zone of inhibition, respectively, against the test organism. The outcomes of the antibacterial screening of the petroleum ether, methanol, and aqueous extracts of S. alata leaves against MRSA are shown in Table 5.

Table 5. Antibacterial activities of leaves extract of $S$. alata against MRSA.

\begin{tabular}{ccc}
\hline Extracts & Mass Concentration $\mathbf{( m g / m L )}$ & Zone of Inhibition $(\mathbf{m m})$ \\
\hline Petroleum ether & 25 & $0.00 \pm 0.00$ \\
Methanol & 25 & $11.0 \pm 0.11$ \\
Aqueous & 25 & $14.5 \pm 0.01$ \\
Oxacillin & 25 & $0.00 \pm 0.00$ \\
\hline
\end{tabular}

The zero values indicate no inhibition.

3.6. Antibacterial Activities of Fractions Obtained from the Crude Aqueous Extracts of S. alata on MRSA

The diethyl ether fraction inhibited the MRSA $(14.00 \pm 0.03 \mathrm{~mm})$. However, the ethylacetate and aqueous fractions were ineffective against the bacterial isolate. The output of antibacterial effects of the ethyl-acetate, diethyl ether, and the crude aqueous leaves extract of $S$. alata against MRSA are presented in Table 6.

Table 6. Antibacterial activities of fractions from the crude aqueous extract of S. alata on MRSA.

\begin{tabular}{ccc}
\hline Fractions & Mass Concentration $(\mathbf{m g} / \mathbf{m L})$ & Zone of Inhibition $(\mathbf{m m})$ \\
\hline Ethyl-acetate & 25 & $0.00 \pm 0.00$ \\
Diethyl ether & 25 & $14.00 \pm 0.03$ \\
Aqueous & 25 & $0.00 \pm 0.00$ \\
\hline
\end{tabular}

The zero values indicate no inhibition.

3.7. Antibacterial Screening of the Various silica Gel Column Eluates of Diethyl ether Fraction Obtained from the Crude Aqueous Leaves Extract of S. alata on MRSA

The result indicated that only sub-fraction 13 of the diethyl ether fraction obtained by eluting the column with n-hexane: ethyl acetate (40:60) produced antibacterial activity $(15.00 \mathrm{~mm} \pm 0.01)$ against the MRSA. The antibacterial effect of the various column eluates of the most active fraction (diethyl ether) is presented in Table 7. 
Table 7. Antibacterial screening of the various silica gel columns eluates of the diethyl ether fraction obtained from the crude aqueous leaves extracts of $S$. alata on MRSA.

\begin{tabular}{ccc}
\hline Sub-Fractions & Mass Concentration $\mathbf{( m g / m L )}$ & Zone of Inhibition $(\mathbf{m m})$ \\
\hline 1 & 200 & $0.00 \pm 0.00$ \\
2 & 200 & $0.00 \pm 0.00$ \\
3 & 200 & $0.00 \pm 0.00$ \\
4 & 200 & $0.00 \pm 0.00$ \\
5 & 200 & $0.00 \pm 0.00$ \\
6 & 200 & $0.00 \pm 0.00$ \\
7 & 200 & $0.00 \pm 0.00$ \\
8 & 200 & $0.00 \pm 0.00$ \\
9 & 200 & $0.00 \pm 0.00$ \\
10 & 200 & $0.00 \pm 0.00$ \\
11 & 200 & $0.00 \pm 0.00$ \\
12 & 200 & $0.00 \pm 0.00$ \\
13 & 200 & $15.00 \pm 0.01$ \\
14 & 200 & $0.00 \pm 0.00$ \\
15 & 200 & $0.00 \pm 0.00$ \\
\hline
\end{tabular}

The zero values indicate no inhibition.

3.8. Antibacterial Screening of the Various Spots of Sub-Fraction 13 of the Diethyl ether Fraction Obtained from Aqueous Leaves Extract of S. alata on MRSA

The result of TLC analysis of the active column eluates (sub-fraction 13) revealed three (3) different spots when the plate was developed with solvent system chloroform: methanol $(4: 1)$. The antibacterial screening of the spots against the MRSA revealed that only spot 2 produced activity against the MRSA $(15.00 \pm 0.05 \mathrm{~mm})$. The antibacterial activity of the various spot of sub-fraction 13 on the MRSA is shown in Table 8.

Table 8. Antibacterials screening of the different spots of sub-fraction 13 obtained from the diethyl ether fraction of aqueous leaves extracts of $S$. alata on MRSA.

\begin{tabular}{ccc}
\hline Spots & $\begin{array}{c}\text { Mass Concentration } \\
(\mathbf{m g} / \mathbf{m L})\end{array}$ & Zone of Inhibition (mm) \\
\hline 1 & 100 & $0.00 \pm 0.00$ \\
2 & 100 & $15.00 \pm 0.05$ \\
3 & 100 & $0.00 \pm 0.00$ \\
\hline
\end{tabular}

The zero values indicate no inhibition.

\subsection{Thin-Layer Chromatographic (TLC) Studies of Diethyl ether Fraction Obtained from Crude Aqueous Leaves Extract of S. alata}

Different colors were observed on exposing the TLC plate of the active diethyl ether fraction of the crude aqueous leaves extracts of $S$. alata to different detecting mediums. Under direct light, bright yellow (spot 1) was observed. When this plate was exposed to ammonia vapor, two spots were observed: yellow (spot 1) and pink (spot 2). Nine yellow spots were observed when the TLC plate was exposed to iodine vapor. These spots changed to various colors when observed under UV light in the presence and absence of ammonia vapor. Viewing the plate under UV light, in the absence of ammonia revealed 9 variedly colored spots: spot 1 purple $(R f=0.96)$, spot 2 blue $(R f=0.94)$, spot 3 light purple $(\mathrm{Rf}=0.80)$, spot 4 orange $(\mathrm{Rf}=0.73)$, spot 5 purple $(R f=0.66)$, spot 6 blue-green $(R f=0.45)$, spot 7 light purple $(R f=0.38)$, spot 8 purple $(R f=0.28)$, and spot 9 purple-green $(R f=0.19)$. However, when the plate was exposed to UV light, in the presence of ammonia, spot 1 changed from purple color to blue color, spot 3 changed to pink color, while spots 2, 4, 5, 6, 7,8 , and 9 appeared as orange, blue-green, green, light purple, light purple, light blue, and green, respectively. 


\subsection{Rf Values and Color of Fraction 13 of Diethyl Ether Obtained from Crude Aqueous Leaves} Extract of S. alata When Viewed under Different Detecting Medium

Different colors were observed on exposing the TLC plate of the fraction 13 of diethyl ether fraction from the crude aqueous leaves extract of $S$. alata to different detecting mediums; direct light, iodine vapor, ammonia vapor, and UV light $(366 \mathrm{~nm})$. The TLC analysis of fraction 13 showed three spots with Rf values of $0.45,0.54$, and 0.93 , signifying varying polarity of the compounds. All three spots turned yellow with iodine vapor. Spot 2 turned pink with ammonia vapor and appeared yellow under UV light $(366 \mathrm{~nm})$, indicating a likely ester compound, while spot 3 turned light-blue under the UV light, indicating a possible aromatic compound as shown in Table 9.

Table 9. Rf values and color of TLC spots of fraction 13 obtained from diethyl ether column eluates of $S$. alata crude aqueous leaves extract when viewed under different detecting mediums.

\begin{tabular}{cccccccc}
\hline Spots & $\mathbf{R}_{\mathbf{f}} \times \mathbf{1 0 0}$ & Iodine Vapor & Ammonia Vapor & Ultra-Violet (UV) & UV/Ammonia & Inference \\
\hline 1 & 45 & $\mathrm{Y}$ & $\mathrm{LP}$ & $\mathrm{Y}$ & $\mathrm{LP}$ & $\mathrm{OC}$ \\
2 & 54 & $\mathrm{Y}$ & $\mathrm{P}$ & $\mathrm{Y}$ & $\mathrm{P}$ & Ester \\
3 & 93 & $\mathrm{Y}$ & $\mathrm{ND}$ & $\mathrm{LB}$ & $\mathrm{B}$ & $\mathrm{AC}$ \\
\hline
\end{tabular}

Rf: Retention factor, DL: Direct light, ND: Not detected, Y: Yellow, P: Pink, B: Blue, LB: Light blue, LP: Light pink, OC: Organic compounds, and AC: Aromatic compounds.

3.11. Infra-Red Spectroscopic Analysis of TLC Spot 2 of the Active Column Eluate of Fraction 13 Obtained from S. alata Diethyl Ether Column Eluate

The FT-IR spectrum of TLC spot 2 from sub-fraction 13 of diethyl ether column eluates was obtained as $\mathrm{KBr}$ disk and shown in Figure 1, which contains seven (7) vibrational bands assigned to their respective functional groups as shown in Table 10. The prominent bands are assignable to O-H $\left(3320 \mathrm{~cm}^{-1}\right), \mathrm{C}-\mathrm{H}$ stretching vibration $\left(2922 \mathrm{~cm}^{-1}\right)$, conjugated $\mathrm{C}=\mathrm{O}$ stretching vibration $\left(1697 \mathrm{~cm}^{-1}\right)$, conjugated $\mathrm{C}=\mathrm{C}$ stretching vibration $\left(1648 \mathrm{~cm}^{-1}\right)$, C-H bending vibration $\left(1514 \mathrm{~cm}^{-1}\right), \mathrm{C}-\mathrm{O}$ stretching vibration $\left(1033 \mathrm{~cm}^{-1}\right)$, and C-H out of plane bending vibration $\left(670 \mathrm{~cm}^{-1}\right)$ bonded to a carbon-carbon double bond $(\mathrm{C}=\mathrm{C})$.

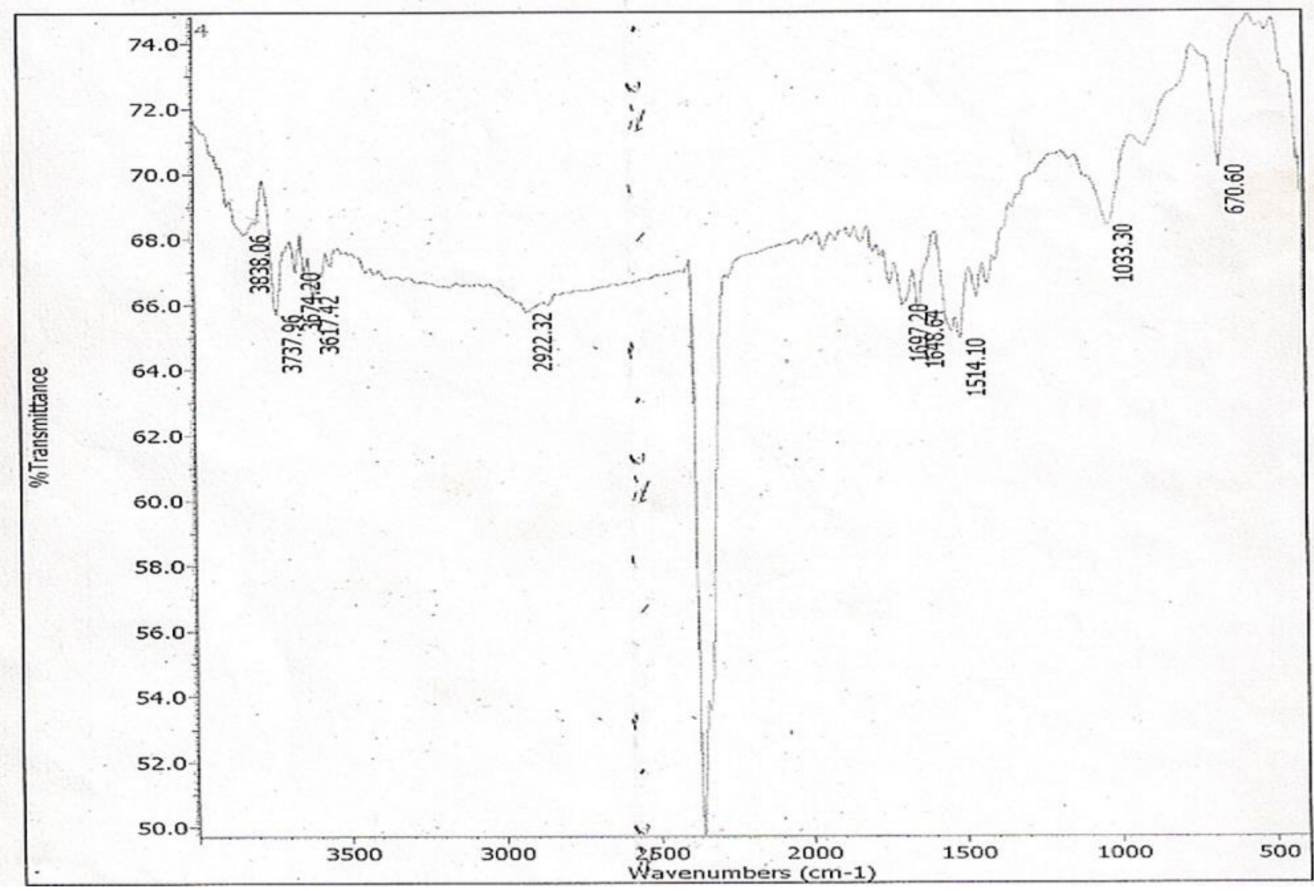

Figure 1. Infrared spectrum of spot 2 of fraction 13 obtained from diethyl ether column eluates. 
Table 10. Infrared bands and assignments of the active TLC spot (spot 2) of fraction 13 obtained from diethyl ether column eluates for $S$. alata.

\begin{tabular}{ccc}
\hline Bands & Wave Number $\left(\mathbf{c m}^{-\mathbf{1}}\right)$ & Assignment \\
\hline 1 & 3320 & O-H Stretching \\
2 & 2922 & C-H Stretching \\
3 & 1697 & C=O Stretching \\
5 & 1514 & C-H Bending \\
6 & 1033 & C-O Stretching \\
7 & 670 & C-H Bending \\
\hline
\end{tabular}

3.12. Gas Chromatography-Mass Spectrometry (GC-MS) of Spot 2 Obtained from Column Fraction 13 Obtained from the S. alata Diethyl Ether Column Eluate

Total ion chromatogram (TIC) of TLC spot 2 of fraction 13 from the diethyl ether column eluates shown in Figure 2 indicated that the most prominent peak (peak 3) eluted at retention time $22.10 \mathrm{~min}$ belongs to TLC spot 2 of fraction 13. The other peaks in the TIC correspond to impurities present in the eluate, which were insignificant except peak 2. The electron impact mass spectrometry (EIMS) spectrum of spot 2 of sub-fraction 13 exhibited prominent peaks that are shown in Figure 3, which indicated a molecular ion peak at $\mathrm{m} / \mathrm{z} 296[\mathrm{M}]^{+}$with the following significant fragment ion peaks at $\mathrm{m} / \mathrm{z}$ $264\left[\mathrm{C}_{19} \mathrm{H}_{36}\right]^{+}, 222\left[\mathrm{C}_{16} \mathrm{H}_{30}\right]^{+}, 180\left[\mathrm{C}_{13} \mathrm{H}_{24}\right]^{+}, 137\left[\mathrm{C}_{12} \mathrm{H}_{17}\right]^{+}, 112\left[\mathrm{C}_{8} \mathrm{H}_{16}\right]^{+}, 98\left[\mathrm{C}_{7} \mathrm{H}_{12}\right]^{+}$, $84\left[\mathrm{C}_{6} \mathrm{H}_{12}\right]^{+}, 83\left[\mathrm{C}_{6} \mathrm{H}_{11}\right]^{+}, 69\left[\mathrm{C}_{5} \mathrm{H}_{9}\right]^{+}, 55\left[\mathrm{C}_{4} \mathrm{H}_{7}\right]^{+}, 41\left[\mathrm{C}_{3} \mathrm{H}_{5}\right]^{+}$, and $40\left[\mathrm{C}_{3} \mathrm{H}_{4}\right]^{+}$. The fragment ion at $\mathrm{m} / \mathrm{z} 264$ corresponding to $\mathrm{C}_{19} \mathrm{H}_{36}{ }^{+}$was formed from the loss of two oxygen atoms (2O) from the fragmentation of the molecular ion at $\mathrm{m} / \mathrm{z} 296[\mathrm{M}]^{+}$. The fragment ion at $\mathrm{m} / \mathrm{z} 84\left[\mathrm{C}_{6} \mathrm{H}_{12}\right]^{+}$indicated the loss of 180 mass $\left[\mathrm{C}_{13} \mathrm{H}_{24}\right]^{+}$ion. Fragment ion loss at $\mathrm{m} / \mathrm{z} 137$ is accompanied by a loss of a carbon-carbon double bond $(\mathrm{C}=\mathrm{C})$, while fragment ion at $\mathrm{m} / \mathrm{z} 55$ is the base peak ion.

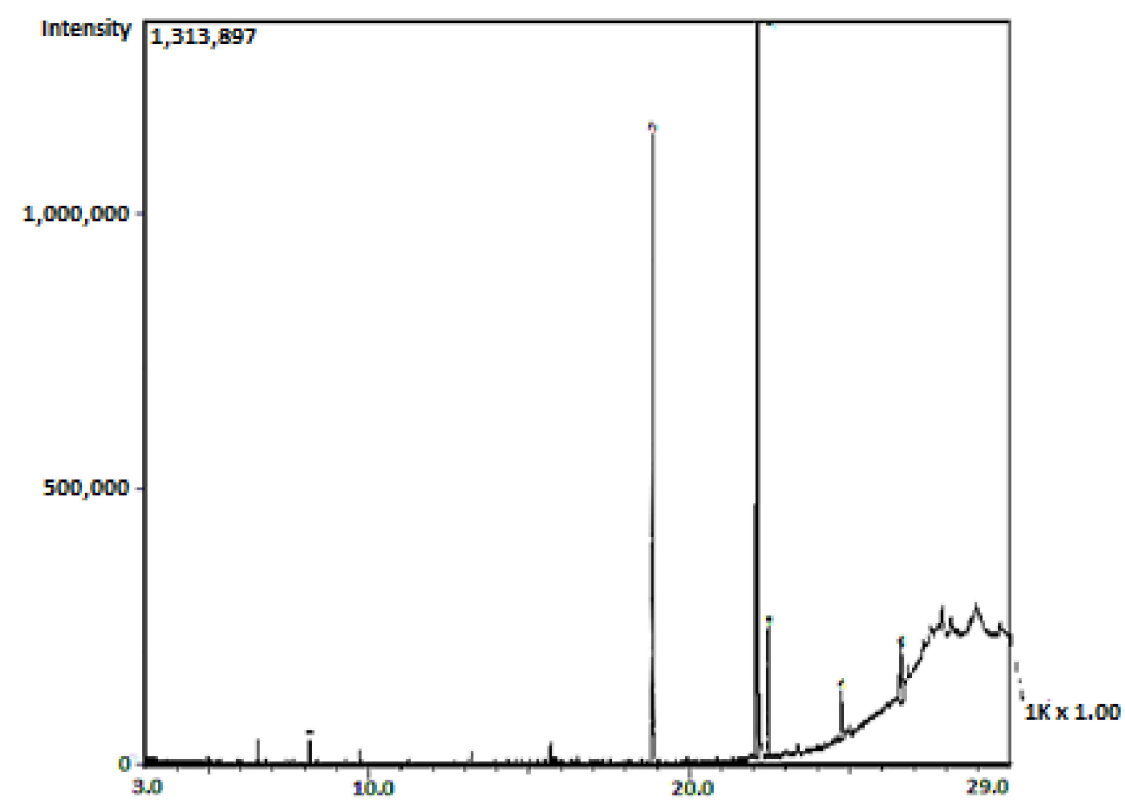

Figure 2. Gas chromatography chromatogram of the diethyl ether fraction 13 active spot (spot 2). 


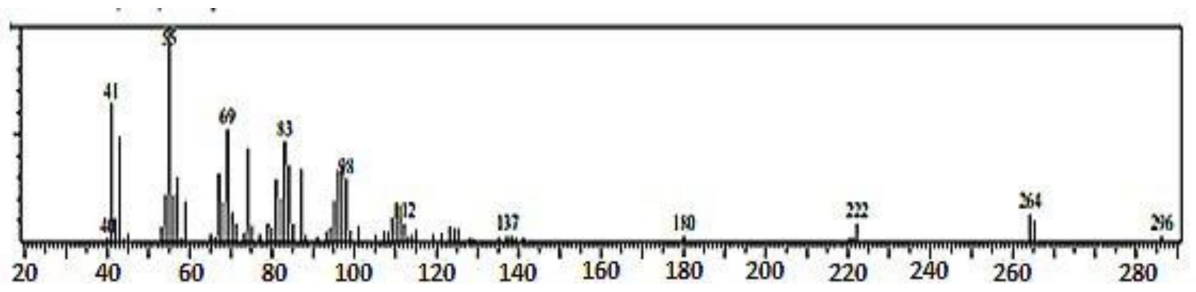

Figure 3. Electron impact mass spectrometry spectrum of spot 2 of fraction 13 obtained from diethyl ether column eluates.

\section{Discussion}

Plant-derived products play a crucial role in exploring active biomolecules to treat infectious diseases, currently causing serious health challenges globally, especially in developing nations [31]. Therefore, it is essential to intensify research on natural products to establish the secondary metabolites responsible for activity against infectious diseases [1,32]. The current study elucidates the antibacterial potentials of various extracts and bioactive components of the aqueous leaves extract of Senna alata against Methicillin-resistant Staphylococcus aureus (MRSA). A compound related to 9-octadecenoic acid methyl ester could be present and may have potent antibacterial activity against MRSA.

Based on the current investigation, the aqueous extract of the plant produced the highest extractive and could contain the highest amount of secondary metabolites present in the plant. Our findings are in line with the work of Saito et al. (2012) [32], where the $100 \mathrm{~g}$ of milled S. alata leaves produced $25.4 \%$ aqueous extract. However, the work of Faruq et al. (2010) [33] has shown that the methanol extract produced the highest yield.

Interestingly, this investigation has shown that the crude aqueous extract of $S$. alata exerted the highest antibacterial effects against the bacteria. Other studies by Adedayo et al. (2001), Modi et al. (2012), Saito et al. (2012), and Somchit et al. (2003) [18,19,32,34] demonstrated the inhibitory effect of aqueous extract of $S$. alata against $S$. aureus, which corroborates with the outcome of this study. On the contrary, a previous report by Faruq et al. (2010) [33] has shown that the S. aureus was resistant to aqueous leaf extract of S. alata. In addition, the antibacterial activity elicited by the methanol extract of $S$. alata against the MRSA in this work agrees with the findings of Hazni et al. (2008) [35] and Sermakkani and Thangapandian (2012) [36]. The difference in the antibacterial activities produced by the methanol and aqueous extracts of $S$. alata leaves in the current work might be related to the secondary metabolites varying degrees of solubility in categories of solvents based on the polarity, which also corroborates with the higher extraction yield in the aqueous extract [37].

Bioassay-guided fractionation is an effective procedure to discover novel therapeutic agents via obtaining active fractions or isolated bioactive agents. In this method, each fraction is usually investigated for biological activity, and subsequently, the most active portions are eventually fractionated for further evaluation [38]. The chemical contents and potential mechanisms of activity of bioactive compounds usually vary in different parts of the plants and a difference in the solubility of the secondary metabolites in different solvents [39]. In this study, the crude aqueous leaves extract of $S$. alata afforded ethylacetate and diethyl ether fractions. However, only the diethyl ether fraction elicited an antibacterial activity related to the higher amount of the bioactive agents in the fraction, as shown by its higher extractive value than the ethyl-acetate fraction.

Phytochemical determination gives an overview of the possible category of the plants' secondary metabolites and their quantity in a particular fraction which could guide the isolation strategy of the bioactive components [40]. Based on this research, the aqueous extract of $S$. alata leaves revealed saponins, alkaloids, emodin, tannins, steroids, anthraquinones, and flavonoids that could be associated with the antibacterial effects. The outcome agrees with the previous research by El-Mahmood and Doughari (2008) [41] and Sule et al. (2011) [42]. Generally, the anti-infective action of plants is related to the 
chemical compounds, including tannins, phenols, saponins, steroids, alkaloids, flavonoids, and many other compounds via various processes [43]. Polyphenol agents such as tannins, flavonoids, and alkaloids possess antimicrobial effects [44,45]. Flavonoids, including quercetin and kaempferol, have antimicrobial actions by inhibiting the action of the bacterial enzymes $[42,46,47]$. The antimicrobial action of flavonoids is also associated with their capability to produce a complex with soluble extracellular proteins and bacterial cell walls, whereas tannins inhibit microbial adhesions, transport proteins, and enzymes [44,48]. In addition, flavonoids destabilize microbial cell membranes [48]. Therefore, these phytochemical compounds in $S$. alata could be responsible for its antimicrobial activities.

The observation in the current work that only sub-fraction 13 of the column fractions of the diethyl ether fraction of the crude aqueous $S$. alata leaves extract showed activity concurs with the work of Faruq et al. (2010) [33], in which only one of the column fractions elicited antibacterial activity. Furthermore, a single spot was observed to possess bioactivity following the active diethyl ether column fraction to silica gel TLC analysis. The bioactive spot (spot 2) of the sub-fraction 13 obtained from the diethyl ether fraction of the crude aqueous leaves extract of $S$. alata being the only spot effective against the test organism possesses a hydroxyl group (-OH) in its structure as shown in its IR spectrum assignable to the vibrational band at $3320 \mathrm{~cm}^{-1}$, which is broad and of low intensity. This is typical of the $-\mathrm{OH}$ group found in fatty acids, and it belongs to - $\mathrm{OH}$ bonded to a carboxyl group carbon atom. The presence of the carboxyl group in the structure of spot 2 of the sub-fraction 13 has been confirmed by the GC-MS spectral data. The loss of two oxygen atoms (2O) from the fragmentation of the molecular ion at $\mathrm{m} / \mathrm{z} 296$ to form the fragment ion peak at $\mathrm{m} / \mathrm{z}$ 264 indicated that this loss of oxygen atom could have emanated from a carboxyl group, which is typical of fatty acids methyl ester [49].

The FT-IR spectrum of spot 2 of sub-fraction 13 showed a carbon-carbon double bond $(C=C)$ due to the stretching vibration band at $1684 \mathrm{~cm}^{-1}$. The presence of this bond was confirmed in the GC-MS spectral data as the fragmentation of the fragment ion at $\mathrm{m} / \mathrm{z} 137$ is accompanied by a loss of carbon-carbon double bond $(\mathrm{C}=\mathrm{C})$ to produce the fragment ion at $\mathrm{m} / \mathrm{z} 112$. The orientation of the $\mathrm{C}=\mathrm{C}$ bond is cis configuration. This is confirmed by the presence of C-H out-of-plane bending vibration $\left(670 \mathrm{~cm}^{-1}\right)$ of an olefinic bond, as the bending vibration at $950-970 \mathrm{~cm}^{-1}$ (characteristic of trans configuration) is absent in the IR spectrum of spot 2 of the sub-fraction 13. Furthermore, the C-H bending vibration at $1514 \mathrm{~cm}^{-1}$ results from the presence of a terminal methyl $\left(\mathrm{CH}_{3}\right)$ group in the eluate. The GC-MS spectral data confirm this as the fragment ion at $\mathrm{m} / \mathrm{z} 83$ loses a methyl group and one hydrogen atom to form the fragment ion at $\mathrm{m} / \mathrm{z} 69$. This is a diagnostic of unsaturated fatty acid with a terminal methyl group [49].

In this work, the IR spectra data of spot 2 of the sub-fraction 13 agrees with that of cis-Octadecenoic acid methyl ester [50]. In addition, the entire fragment ions in the GC-MS spectra data of spot 2 of the active sub-fraction 13, including the molecular ion and base peak ion, are in line with the data reported for methyl 9-octadecenoate by Yayli et al. (2001) [29]. Therefore, based on the data presented in this work and the literature, and by comparing with the library search result, spot 2 of the active sub-fraction 13 was determined to be 9-octadecenoic acid methyl ester (E). Furthermore, the molecular formula of the active spot 2 of the sub-fraction 13 was deduced as $\left(\mathrm{C}_{19} \mathrm{H}_{35} \mathrm{O}_{2}\right)$ based on the information obtained from its molecular ion at $\mathrm{m} / \mathrm{z} 296$; this was supported by the findings of Igwe and Onwu (2015) [51] that the oleic acid was 75.03 of total essential oil of S. alata leaf extract using GC-MS. Rahman et al. (2006) [52] have also shown that oleic acids are among the major fatty acids present in S. alata, confirming the presence of fatty acids in the $S$. alata leaves in the current work. Many researchers, including Ogunwande et al. (2010) [53], Adiana and Mazura (2011) [54], and Thenmozhi and Rajan (2015) [55], have previously used FT-IR spectroscopy and GC-MS to analyze the various phytocompounds.

The antibacterial action of the active spot 2, which seems to be a fatty acid methyl ester based on the library search and spectral analysis, is in line with the findings of Igwe and Onwu (2015) [51], who reported the antibacterial effects of essential oil from S. alata 
leaves extract against S. aureus. Similar reports by Kabara et al. (1972) [56], Knapp and Melly (1986) [57], Farrington et al. (1992) [58], and Sun et al. (2003) [59] have shown that long-chain unsaturated fatty acids, including oleic acids found naturally, are effective bactericidal against pathogens including MRSA. In addition, Zheng et al. (2005) [60] in their work reported the effectiveness of unsaturated fatty acid esters and unsaturated fatty acids esters derivatives against $S$. aureus and MRSA. However, the precise mechanism of antibacterial action is precisely unknown. These reports support the observation made on the antibacterial activity of the identified compound against MRSA in the present study, which could explain the traditional applications of $S$. alata in treating bacterial infections.

\section{Conclusions}

The Senna alata leaves possess varying degrees of antibacterial activities against MRSA. The antimicrobial activity of the plant against MRSA was likely due to the 9-Octadecenoic acid methyl ester related component of the plant. In addition, 9-Octadecenoic acid methyl ester related compound could serve as a lead compound for further development to discover novel therapeutic agents as an alternative treatment for drug-resistant bacterial infections. Further spectroscopic studies, such as a proton nuclear magnetic resonance (NMR), are required to ascertain the structure of the identified compound. Additionally, pharmacological and toxicity studies on the identified phytochemical constituents should be conducted to establish the molecular basis for its antibacterial action and safety profile.

Author Contributions: Conceptualization, S.M.L., S.I., K.M.Y., and O.S.O.; methodology, Y.W., M.M., M.H.A., and S.M.; software, Y.W., M.M., M.H.A., and S.M.; validation, S.M.L., A.S., and Z.A.R.; formal analysis, S.M.L., Y.W., M.M., M.H.A., and S.M.; investigation, S.M.L., S.I., K.M.Y., and O.S.O.; resources, S.M.L., Y.W., M.M., and A.S.; data curation, S.A., M.H.A., and Z.A.R.; writing-original draft preparation, S.M.L., S.I., K.M.Y., O.S.O., and A.S.; writing-review and editing, Y.W., M.M., M.H.A., S.M., and Z.A.R.; supervision, S.I., K.M.Y., and O.S.O.; project administration, Y.W., M.M., M.H.A., and S.M.; and funding acquisition, M.M. and A.S. All authors have read and agreed to the published version of the manuscript.

Funding: This research received no external funding.

Institutional Review Board Statement: The study was conducted according to the guidelines of the Declaration of Helsinki, and approved by the Ethics Committee of Ahmadu Bello University, ABU Committee on Animal Use and Care (ABUCAUC/2009/023).

Data Availability Statement: All data related to the manuscript are presented in the manuscript. The raw data can be obtained from the corresponding author based on reasonable requests.

Acknowledgments: The authors are thankful to the academic and non-academic staff of the Department of Pharmacognosy and Drug Development, Ahmadu Bello University, Zaria, Kaduna, Nigeria, for their support during the conduct of the study. The USM Fellowship covers YW. A preprint of the manuscript was deposited on PREPRINTS available at https://www.preprints.org/manuscript/20 2109.0193/v1, accessed on 25 October 2021.

Conflicts of Interest: The authors declare no conflict of interest.

\section{References}

1. Etame, R.M.E.; Mouokeu, R.S.; Poundeu, F.S.M.; Voukeng, I.K.; Cidjeu, C.L.P.; Tiabou, A.T.; Yaya, A.J.G.; Ngane, R.A.N.; Kuiate, J.R.; Etoa, F.X. Effect of fractioning on antibacterial activity of n-butanol fraction from Enantia chlorantha stem bark methanol extract. BMC Complement. Altern. Med. 2019, 19, 56. [CrossRef]

2. Nair, J.J.; Wilhelm, A.; Bonnet, S.L.; van Staden, J. Antibacterial constituents of the plant family Amaryllidaceae. Bioorganic Med. Chem. Lett. 2017, 27, 4943-4951. [CrossRef]

3. David, M.Z.; Daum, R.S. Community-Associated Methicillin-Resistant Staphylococcus aureus: Epidemiology and Clinical Consequences of an Emerging Epidemic. Clin. Microbiol. Rev. 2010, 23, 616-687. [CrossRef] [PubMed]

4. Kale, P.; Dhawan, B. The changing face of community-acquired methicillin-resistant Staphylococcus aureus. Indian J. Med Microbiol. 2016, 34, 275-285. [CrossRef] [PubMed]

5. Dadashi, M.; Nasiri, M.J.; Fallah, F.; Owlia, P.; Hajikhani, B.; Emaneini, M.; Mirpour, M. Methicillin-resistant Staphylococcus aureus (MRSA) in Iran: A systematic review and meta-analysis. J. Glob. Antimicrob. Resist. 2018, 12, 96-103. [CrossRef] 
6. Gibbons, S. Phytochemicals for Bacterial Resistance-Strengths, Weaknesses and Opportunities. Planta Medica 2008, 74, 594-602. [CrossRef]

7. Omoshaba, E.O.; Ojo, O.E.; Oyekunle, M.A.; Sonibare, A.O.; Adebayo, A.O. Methicillin-resistant Staphylococcus aureus (MRSA) isolated from raw milk and nasal swabs of small ruminants in Abeokuta, Nigeria. Trop. Anim. Heal. Prod. 2020, 52, $2599-2608$. [CrossRef]

8. Xie, Y.; Yang, W.; Tang, F.; Chen, X.; Ren, L. Antibacterial Activities of Flavonoids: Structure-Activity Relationship and Mechanism. Curr. Med. Chem. 2014, 22, 132-149. [CrossRef] [PubMed]

9. Ahmad, M.H.; Jatau, A.I.; Khalid, G.M.; Alshargi, O.Y. Traditional uses, phytochemistry, and pharmacological activities of Cochlospermum tinctorium A. Rich (Cochlospermaceae): A review. Futur. J. Pharm. Sci. 2021, 7, 1-13. [CrossRef]

10. Ahmad, M.H.; Jatau, A.I.; Alshargi, O.Y.; Julde, S.M.; Mohammed, M.; Muhammad, S.; Mustapha, S.; Bala, A.A.; Wada, A.S.; Aminu, M.; et al. Ethnopharmacological uses, phytochemistry, pharmacology, and toxicology of Olax subscorpioidea Oliv (Olacaceae): A review. Futur. J. Pharm. Sci. 2021, 7, 1-13. [CrossRef]

11. Atanasov, A.G.; Waltenberger, B.; Pferschy-Wenzig, E.-M.; Linder, T.; Wawrosch, C.; Uhrin, P.; Temml, V.; Wang, L.; Schwaiger, S.; Heiss, E.; et al. Discovery and resupply of pharmacologically active plant-derived natural products: A review. Biotechnol. Adv. 2015, 33, 1582-1614. [CrossRef]

12. Bajalan, I.; Rouzbahani, R.; Pirbalouti, A.G.; Maggi, F. Chemical Composition and Antibacterial Activity of IranianLavandula $\times$ hybrida. Chem. Biodivers. 2017, 14, e1700064. [CrossRef]

13. Barbieri, R.; Coppo, E.; Marchese, A.; Daglia, M.; Sobarzo-Sánchez, E.; Nabavi, S.F. Phytochemicals for human disease: An update on plant-derived compounds antibacterial activity. Microbiol. Res. 2017, 196, 44-68. [CrossRef]

14. Slobodníková, L.; Fialová, S.; Rendeková, K.; Kováč, J.; Mučaji, P. Antibiofilm Activity of Plant Polyphenols. Molecules 2016, 21, 1717. [CrossRef] [PubMed]

15. Ahmad, M.H.; Zezi, A.U.; Anafi, S.B.; Alhassan, Z.; Mohammed, M.; Danraka, R.N. Mechanisms of antidiarrhoeal activity of methanol leaf extract of Combretum hypopilinum diels (combretaceae): Involvement of opioidergic and ( $\alpha 1$ and $\beta$ )-adrenergic pathways. J. Ethnopharmacol. 2020, 269, 113750. [CrossRef]

16. Oladeji, O.S.; Adelowo, F.E.; Oluyori, A.P.; Bankole, D.T. Ethnobotanical Description and Biological Activities of Senna alata. Evidence-Based Complement. Altern. Med. 2020, 2020, 1-12. [CrossRef]

17. Yakubu, M.T.; Musa, I.F. Effects of Post-coital Administration of Alkaloids from Senna alata (Linn. Roxb) Leaves on some Fetal and Maternal Outcomes of Pregnant Rats. J. Reprod. Infertil. 2012, 13, 211-217. [PubMed]

18. Adedayo, O.; Anderson, W.; Moo-Young, M.; Snieckus, V.; Patil, P.; Kolawole, D. Phytochemistry and Antibacterial Activity of Senna alata Flower. Pharm. Biol. 2001, 39, 408-412. [CrossRef]

19. Somchit, M.; Reezal, I.; Nur, I.; Mutalib, A. In vitro antimicrobial activity of ethanol and water extracts of Cassia alata. J. Ethnopharmacol. 2002, 84, 1-4. [CrossRef]

20. Igoli, J.O.; Igwue, I.C.; Igoli, N.P. Traditional medicinal practices among the Igede people of Nigeria. J. Herbs Spices Med. Plants 2004, 10, 1-10. [CrossRef]

21. Kupchan, S.M.; Britton, R.W.; Ziegler, M.F.; Sigel, C.W. Bruceantin, a new potent antileukemic simaroubolide from Brucea antidysenterica. J. Org. Chem. 1973, 38, 178-179. [CrossRef] [PubMed]

22. Sofowora, A. Medicinal Plants and Traditional Medicine in Africa, 2nd ed.; Spectrum Books Ltd.: Ibadan, Nigeria, 1993.

23. Harborne, J.B. Phytochemical Methods, A Guide to Modern Techniques of Plant Analysis; Chapman and Hall, Ltd.: London, UK, 1973.

24. Bohm, M.; Kocipai, A. Flavonoids Composition and Uses; Smith Sonian institution Press: Washington, DC, USA, 1994.

25. Pearson, D. Chemical Analysis of Food; Churchill Livingston: Edinburgh, UK, 1976.

26. Onwuka, B. Food Analysis and Instrumentation Theory and Practical; Naphtali Prints: Lagos, Nigeria, 2005.

27. AOAC. Official Methods of Analysis of the Association of Official Analytical Chemist, 14th ed.; AOAC: Washinton, DC, USA, 1984.

28. Devillers, J.; Steiman, R.; Seigle-Murandi, F. The usefulness of the agar-well diffusion method for assessing chemical toxicity to bacteria and fungi. Chemosphere 1989, 19, 1693-1700. [CrossRef]

29. Yayli, N.; Kiran, Z.; Seymen, H.; Genc, H. Characterization of Lipids and Fatty Acid Methyl Ester Contents in Leaves and Roots of Crocus vallicola. Turk. J. Chem. 2001, 25, 391-395.

30. Rahman, M.S.; Ali, M.Y.; Ali, M.U. In vitro screening of two flavonoids compounds isolated from cassia alata leaves for fungicidal activities. J. Biol. Sci. 2008, 16, 139-142. [CrossRef]

31. Voukeng, I.K.; Nganou, B.K.; Sandjo, L.P.; Celik, I.; Beng, V.P.; Tane, P.; Kuete, V. Antibacterial activities of the methanol extract, fractions and compounds from Elaeophorbia drupifera (Thonn.) Stapf. (Euphorbiaceae). BMC Complement. Altern. Med. 2017, 17, 28. [CrossRef]

32. Saito, S.T.; Trentin, D.; Macedo, A.J.; Pungartnik, C.; Gosmann, G.; Silveira, J.D.D.; Guecheva, T.N.; Henriques, J.A.P.; Brendel, M. Bioguided fractionation shows Cassia alata extract to Inhibit Staphylococcus epidermidis and Pseudomonas aeruginosa Growth and Biofilm Formation. Evidence-Based Complement. Altern. Med. 2012, 2012, 1-13. [CrossRef] [PubMed]

33. Faruq, Z.; Rahman, U.; Bello, M.; Obianke, M.; Atiku, F. Antibacterial activity of the active Component of Cassia alata (Linn) Leaves. Niger. J. Basic Appl. Sci. 2010, 18, 97-100. [CrossRef]

34. Modi, C.; Mody, S.; Patel, H.; Dudhatra, G.; Kumar, A.; Awale, M. Herbal antibacterials: A review. J. Intercult. Ethnopharmacol. 2012, 1, 52-61. [CrossRef] 
35. Hazni, H.; Ahmad, N.; Hitotsuyanagi, Y.; Takeya, K.; Choo, C.-Y. Phytochemical Constituents from Cassia alata with Inhibition against Methicillin-Resistant Staphylococcus aureus (MRSA). Planta Med. 2008, 74, 1802-1805. [CrossRef] [PubMed]

36. Sermakkani, M.; Thangapandian, V. GC-MS Analysis of Cassia italica Leaf Methanol Extract. Asian J. Pharm. Clin. Res. 2012, 5, 90-94.

37. Mabotja, M.; Venter, S.; Du Plooy, C.; Kudanga, T.; Amoo, S. Phytochemical Content, Antioxidant, Alpha-Glucosidase Inhibitory and Antibacterial Activities of Spineless Cactus Pear Cultivars. Plants 2021, 10, 1312. [CrossRef]

38. Rufatto, L.C.; Luchtenberg, P.; Garcia, C.; Thomassigny, C.; Bouttier, S.; Henriques, J.A.P.; Roesch-Ely, M.; Dumas, F.; Moura, S. Brazilian red propolis: Chemical composition and antibacterial activity determined using bioguided fractionation. Microbiol. Res. 2018, 214, 74-82. [CrossRef]

39. Lutfullah, G.; Shah, A.; Ahmad, K.; Haider, J. Phytochemical screening, antioxidant and antibacterial properties of daphne mucronata. J. Tradit. Chin. Med. 2019, 39, 764-771.

40. Bhatnagar, M.; Sarkar, N.; Gandharv, N.; Apang, O.; Singh, S.; Ghosal, S. Evaluation of antimycobacterial, leishmanicidal and antibacterial activity of three medicinal orchids of Arunachal Pradesh, India. BMC Complement. Altern. Med. 2017, 17, 379. [CrossRef] [PubMed]

41. El-Mahmood, A.M.; Doughari, J.H. Phytochemical screening and antibacterial evaluation of the leaf and root extracts of Cassia alata Linn. Afr. J. Pharmacol. Pharmacogn. 2008, 2, 124-129.

42. Sule, W.F.; Okonko, I.O.; Omo-Ogun, S.; Nwanze, J.C.; Ojezele, M.O.; Ojezele, O.J.; Alli, J.A.; Soyemi, E.T.; Olaonipekun, T.O. Phytochemical properties and in-vitro antifungal activity of Senna alata Linn. crude stem bark extract. J. Med. Plants Res. 2011, $5,176-183$.

43. Abdulmalik, I.; Sule, M.; Yaro, A.; Abdullahi, M.; Abdulkadir, M.; Yusuf, H. Evaluation of analgesic and anti-inflammatory effects of ethanol extract of Ficus iteophylla leaves in rodents. Afr. J. Tradit. Complement. Altern. Med. 2011, 8, 462-466. [CrossRef]

44. Mogana, R.; Adhikari, A.; Tzar, M.N.; Ramliza, R.; Wiart, C. Antibacterial activities of the extracts, fractions and isolated compounds from Canarium patentinervium Miq. against bacterial clinical isolates. BMC Complement. Med. Ther. 2020, 20, 55. [CrossRef]

45. Vu, T.T.; Kim, H.; Tran, V.K.; Vu, H.D.; Hoang, T.X.; Han, J.W.; Choi, Y.H.; Jang, K.S.; Choi, G.J.; Kim, J.-C. Antibacterial activity of tannins isolated from Sapium baccatum extract and use for control of tomato bacterial wilt. PLoS ONE 2017, 12, e0181499. [CrossRef]

46. Cushnie, T.T.; Lamb, A.J. Antimicrobial activity of flavonoids. Int. J. Antimicrob. Agents 2005, 26, 343-356. [CrossRef]

47. Cushnie, T.T.; Lamb, A. Recent advances in understanding the antibacterial properties of flavonoids. Int. J. Antimicrob. Agents 2011, 38, 99-107. [CrossRef] [PubMed]

48. Sharma, A.; Rawat, S.; Verma, R.; Vishwavidyalaya, R.D. Identification of antibacterial components of some Indian medicinal plants against Klebsiella pneumoniae. Int. J. Pharm. Pharm. Sci. 2010, 2, 123-127.

49. Oyugi, D.A.; Ayorinde, F.O.; Gugssa, A.; Allen, A.; Izevbigie, E.B.; Eribo, B.; Anderson, W.A. Biological activity and mass spectrometric analysis of Vernonia amygdalina fractions. J. Biosci. Technol. 2011, 2, 287-304.

50. Kaneshiro, T.; Marr, A.G. cis-9,10-Methylene hexadecanoic acid from the phospholipids of Escherichia coli. J. Biol. Chem. 1961, 236, 2615-2619. [CrossRef]

51. Igwe, O.U.; Onwu, F.K. Leaf essential oil of Senna alata Linn from Southeast Nigeria and its Antimicrobial activity. Int. J. Research Pharm. Chem. 2015, 5, 27-33.

52. Rahman, M.S.; Ali, M.Y.; Ali, M.U.; Moynul, A.J.M. Studies on the Lipid and Glyceride Compositions of Cassia alata Seed Oil. Bangladesh J. Sci. Ind. Res. 2006, 41, 83-88. [CrossRef]

53. Ogunwande, I.A.; Flamini, G.; Cioni, P.L.; Omikorede, O.; Azeez, R.A.; Ayodele, A.A.; Kamil, Y.O. Aromatic Plants growing in Nigeria: Essential Oil Constituents of Cassia alata (Linn.) Roxb. and Helianthus annuus L. Rec. Nat. Prod. $2010,4,211-217$.

54. Adiana, M.A.; Mazura, M.P. Study on Senna alata and its different extracts by Fourier transform infrared spectroscopy and two-dimensional correlation infrared spectroscopy. J. Mol. Struct. 2011, 991, 84-91. [CrossRef]

55. Thenmozhi, S.; Rajan, S. GC-MS analysis of bioactive compounds in Psidium guajava leaves. J. Pharmacogn. Phytochem. 2015, 3, 162-166.

56. Kabara, J.J.; Swieczkowski, D.M.; Conley, A.J.; Truant, J.P. Fatty Acids and Derivatives as Antimicrobial Agents. Antimicrob. Agents Chemother. 1972, 2, 23-28. [CrossRef] [PubMed]

57. Knapp, H.R.; Melly, M.A. Bactericidal Effects of Polyunsaturated Fatty Acids. J. Infect. Dis. 1986, 154, 84-94. [CrossRef] [PubMed]

58. Farrington, M.; Brenwald, N.; Haines, D.; Walpole, E. Resistance to desiccation and skin fatty acids in outbreak strains of methicillin-resistant Staphylococcus aureus. J. Med. Microbiol. 1992, 36, 56-60. [CrossRef]

59. Sun, C.Q.; Connor, C.J.O.; Roberton, A.M. Antibacterial actions of fatty acids and monoglycerides against Helicobacter pylori. FEMS Immunol. Med. Microbiol. 2003, 36, 9-17. [CrossRef]

60. Zheng, C.J.; Yoo, J.; Lee, T.; Cho, H.; Kim, Y.-H.; Kim, W.-G. Fatty acid synthesis is a target for antibacterial activity of unsaturated fatty acids. FEBS Lett. 2005, 579, 5157-5162. [CrossRef] [PubMed] 